\title{
Proteolytic enzymes and gonadal hormones of the ovarian follicle wall during ovulation in the domestic fowl (Gallus domesticus)
}

\author{
H. Tojo, M. Fujii and K. Ogawa \\ Department of Animal Science, Kagoshima University, Kagoshima, 890 Japan
}

\begin{abstract}
Summary. There were no significant changes in the activities of collagenase, acid and neutral protease up to ovulation. Neutral protease activity increased significantly in the post-ovulatory follicle obtained immediately after ovulation. Acid protease and collagenase showed an increasing activity with time after ovulation. The progesterone concentration of the follicle wall rose $3 \mathrm{~h}$ before ovulation, peaked $1 \mathrm{~h}$ before ovulation and remained high until ovulation. Plasma progesterone values were high but decreased before those in the follicle. Follicular progesterone concentrations decreased markedly soon after rupture, but oestradiol values then increased.
\end{abstract}

\section{Introduction}

Mammalian ovulation is associated with an extensive degradation (Espey, 1967b; Parr, 1974; Pendergrass \& Reber, 1980) and a subsequent reduction in the tensile strength of the follicle wall (Rondell, 1964; Espey, 1967a). Similar degradation of the follicular structures can be induced by proteolytic enzymes applied to the surface of the follicle both in vivo and in vitro (Espey \& Lipner, 1965; Espey, 1970; Nakajo, Zakaria \& Imai, 1973). Several studies suggest that proteolytic enzymes in the follicle wall may be important in the degradation of the follicle structure at ovulation in mammals and birds (Espey \& Lipner, 1965; Espey \& Rondell, 1968; Espey, 1970; Nakajo et al., 1973; Nakamura \& Nakajo, 1980). There are few reports on the biochemical changes which occur in the follicle wall of birds during ovulation (Nakamura \& Nakajo, 1980). We therefore investigated the changes in proteolytic enzymes and gonadal hormones of the ovarian follicle wall during ovulation in the domestic fowl.

\section{Materials and Methods}

White Leghorn hens with 5 or 6 eggs in a clutch were used. The hens, kept in individual cages, were exposed to $14 \mathrm{~h}$ light $/ 24 \mathrm{~h}(06: 00-20: 00 \mathrm{~h})$ and provided with food and water ad libitum. The time sequence of oviposition was recorded individually for 4 weeks immediately before the initiation of the experiment. The time of ovulation was estimated from the laying records. Immediately after blood collection from the wing vein, hens were killed at various times before and after $(-9$ to $+15 \mathrm{~h})$ the predicted time of $\mathrm{C}_{2}$ ovulation. The largest primary follicle or the postovulatory follicle was removed from the ovary. In some hens which had been killed shortly before the predicted ovulation, the largest follicle had already ruptured. The follicles were therefore classified into those obtained shortly before ovulation (Group 1) and those removed shortly after ovulation (Group 2). The actual ovulation time for the postovulatory follicle was estimated by the location of the ovulated ovum in the oviduct. Blood plasma was separated by 
centrifugation at $4^{\circ} \mathrm{C}$ and stored at $-20^{\circ} \mathrm{C}$ until used. The follicle wall was separated from the yolk after being frozen on solid $\mathrm{CO}_{2}$. Each follicle wall and postovulatory follicle was weighed, minced and homogenized with 5 volumes of $0.01 \mathrm{M}-\mathrm{CaCl}_{2}$ containing $0.025 \%$ Triton X-100. The homogenate was centrifuged at $4^{\circ} \mathrm{C}$ for $20 \mathrm{~min}$. After washing the precipitate with a small volume of the same solution, the suspension was centrifuged again and the supernatant was combined and diluted to $5 \mathrm{ml}$ total volume. The precipitate was suspended in $0.1 \mathrm{M}-\mathrm{Tris}-\mathrm{HCl}$ to reach a final volume of $5 \mathrm{ml}$ per follicle. The preparations were stored at $-20^{\circ} \mathrm{C}$ and used within 1 month for enzyme assay. Plasma concentrations of oestradiol and progesterone were measured. The supernatant of the homogenized follicle tissue was used for the assay of acid protease and oestradiol and progesterone. The activity of neutral protease and collagenase was measured in suspensions of the precipitate.

\section{Enzyme assay}

The activities of the neutral and acid proteases were measured by using casein or haemoglobin as a substrate at $\mathrm{pH} 7.0$ and 4.0 respectively. The assay media were incubated at $41^{\circ} \mathrm{C}$ for $30 \mathrm{~min}$. The reaction was stopped by adding $5 \%(\mathrm{w} / \mathrm{v})$ trichloroacetic acid. After centrifugation at $1500 \mathrm{~g}$ for $20 \mathrm{~min}$, the absorbance of the supernatant was measured at $280 \mathrm{~nm}$. One unit is defined as the amount of enzyme that catalyses the formation of $1 \mu \mathrm{mol}$ tyrosine/30 min under the assay conditions. Collagenolytic activity was determined at $\mathrm{pH} 8.0$ by using a synthetic peptide, DNP-Pro-Leu-Gly-Ile-Ala-Gly-Arg. $\mathrm{NH}_{2}$ (Peptide Institute Protein Research Foundation, Osaka, Japan) as a substrate. The media were incubated at $41^{\circ} \mathrm{C}$ for $4 \mathrm{~h}$. The reaction was stopped by addition of $1 \mathrm{~N}-\mathrm{HCl}$ and then ethyl acetate was added. After centrifugation at $1500 \mathrm{~g}$ for $20 \mathrm{~min}$, the absorbance of the supernatant (ethyl acetate) was determined at $365 \mathrm{~nm}$. The activity was expressed as nmol released DNP-tripeptide/h (DNP unit), using the molar extinction co-efficient, $1.76 \times 10^{4}$ at $365 \mathrm{~nm}$.

\section{Assay of hormones}

Oestradiol and progesterone concentrations in the plasma and the follicle tissue were determined by the radioimmunoassay previously validated (Tojo \& Huston, 1981). [2,4,6,7$\left.{ }^{3} \mathrm{H}(\mathrm{N})\right]$ Oestradiol and $\left[1,2,6,7-{ }^{3} \mathrm{H}(\mathrm{N}) \mid\right.$ progesterone were obtained from New England Nuclear Co. (Boston, Massachusetts, U.S.A.). Rabbit antisera against oestradiol and progesterone were purchased from Teikoku-zoki Co. (Tokyo, Japan) and used at a dilution of 1:20000 and of $1: 25000$ respectively. An antiserum to 6-oxoestradiol-17 $\beta-6-C M O-B S A$ cross-reacted $100 \%$ to oestradiol- $17 \beta, 5 \cdot 3 \%$ to 16 -epioestriol, $8 \cdot 0 \%$ to oestrone- 3 -sulphate, $3 \cdot 2 \%$ to oestrone, $1 \cdot 8 \%$ to oestriol and $<1.0 \%$ to the other 14 steroids tested. An antiserum to progesterone3-oxime-BSA cross-reacted $100 \%$ to progesterone, $42.6 \%$ to $5 \alpha$-pregnanedione, $6.7 \%$ to $20 \alpha$-dihydroprogesterone, $6.6 \%$ to 11 -desoxycorticosterone, $1.5 \%$ to pregnenolone and $<1.0 \%$ to the other steroids. The sensitivity of the assay was $15.6 \mathrm{pg}$ oestradiol $/ \mathrm{ml}$ and $31.3 \mathrm{pg}$ progesterone $/ \mathrm{ml}$. The recoveries of oestradiol and progesterone from the plasma were $78 \cdot 5 \pm 5 \cdot 8 \%(n=5)$ and $76 \cdot 8 \pm 4 \cdot 7 \%(n=5)$, respectively. The recoveries from the tissue extract were $77.4 \pm 3.9 \%(n=5)$ for the oestradiol and $76.3 \pm 4.4 \%(n=5)$ for the progesterone assay. Dextran-coated charcoal in phosphate-buffered saline solution was used to separate the bound and the unbound steroid. The hormone concentrations of the samples were calculated by comparison to standard curves composed of 8 points ranging from 16 to 2000 $\mathrm{pg} / \mathrm{ml}$ for both steroids. 


\section{Results}

There were no appreciable changes in the weight of the follicle wall from $9 \mathrm{~h}$ before ovulation until rupture (Table 1). After ovulation, the postovulatory follicle significantly degenerated with time. No significant changes in the activities of the enzymes were observed until ovulation (Table 1). The collagenolytic and acid protease activity increased after rupture and continued to increase with time. There was a slight decrease in the neutral protease activity just before ovulation. A significant increase in the neutral protease activity was observed in the postovulatory follicle collected a few minutes after ovulation, but the activity decreased thereafter. Plasma oestradiol concentrations began to increase $6 \mathrm{~h}$ before ovulation and showed a conspicuous rise after ovulation. There were no marked changes of oestradiol in the follicle wall until ovulation but values increased after ovulation (Table 2). The progesterone concentration of the follicle wall rose markedly $3 \mathrm{~h}$ before ovulation and remained high until just before ovulation, falling drastically after ovulation. By contrast, plasma progesterone values began to decrease $1 \mathrm{~h}$ before ovulation (Table 2).

Table 1. Activities of collagenase, acid and neutral protease in the ovarian follicle wall before and after ovulation in the hen

\begin{tabular}{cccccc}
\hline $\begin{array}{c}\text { Hours before (-) } \\
\text { or after }(+) \\
\text { ovulation }\end{array}$ & $\begin{array}{c}\text { No. of } \\
\text { hens }\end{array}$ & $\begin{array}{c}\text { Follicle wall } \\
\text { wt }(\mathrm{mg})\end{array}$ & Collagenase & Acid protease & Neutral protease \\
\cline { 4 - 6 } & 6 & $432 \pm 32^{\mathrm{a}}$ & $37 \cdot 2 \pm 3 \cdot 3^{\mathrm{a}}$ & $1 \cdot 05 \pm 0 \cdot 16^{\mathrm{a}}$ & $1.92 \pm 0 \cdot 11^{\mathrm{a}}$ \\
-9 & 6 & $428 \pm 27^{\mathrm{a}}$ & $35 \cdot 5 \pm 2 \cdot 5^{\mathrm{a}}$ & $1 \cdot 17 \pm 0 \cdot 16^{\mathrm{a}}$ & $1 \cdot 96 \pm 0 \cdot 13^{\mathrm{a}}$ \\
-6 & 6 & $424 \pm 18^{\mathrm{a}}$ & $30 \cdot 8 \pm 3 \cdot 3^{\mathrm{a}}$ & $1 \cdot 45 \pm 0 \cdot 31^{\mathrm{a}}$ & $1.99 \pm 0 \cdot 17^{\mathrm{a}}$ \\
-3 & 4 & $420 \pm 26^{\mathrm{a}}$ & $34 \cdot 7 \pm 3 \cdot 2^{\mathrm{a}}$ & $1 \cdot 45 \pm 0 \cdot 16^{\mathrm{a}}$ & $1.93 \pm 0 \cdot 18^{\mathrm{a}}$ \\
-1 & 7 & $419 \pm 26^{\mathrm{a}}$ & $39 \cdot 4 \pm 1.9^{\mathrm{a}}$ & $1 \cdot 46 \pm 0 \cdot 17^{\mathrm{a}}$ & $1 \cdot 57 \pm 0 \cdot 13^{\mathrm{a}, \mathrm{c}, \mathrm{d}}$ \\
$0\{$ Group 1 & 7 & $415 \pm 17^{\mathrm{a}}$ & $44 \cdot 7 \pm 4 \cdot 5^{\mathrm{a}}$ & $1 \cdot 50 \pm 0 \cdot 17^{\mathrm{a}}$ & $2 \cdot 54 \pm 0 \cdot 14^{\mathrm{b}}$ \\
+1 & 5 & $388 \pm 34^{\mathrm{a}, \mathrm{b}}$ & $50 \cdot 9 \pm 8 \cdot 0^{\mathrm{a}, \mathrm{b}}$ & $2 \cdot 00 \pm 0 \cdot 13^{\mathrm{a}, \mathrm{b}}$ & $2 \cdot 19 \pm 0 \cdot 21^{\mathrm{a}, \mathrm{b}, \mathrm{c}}$ \\
+2 & 5 & $348 \pm 30^{\mathrm{b}}$ & $61 \cdot 3 \pm 6 \cdot 7^{\mathrm{b}}$ & $2 \cdot 17 \pm 0 \cdot 12^{\mathrm{b}}$ & $1.67 \pm 0 \cdot 13^{\mathrm{a}, \mathrm{c}}$ \\
+15 & 5 & $269 \pm 33^{\mathrm{b}}$ & $66 \cdot 7 \pm 4 \cdot 7^{\mathrm{b}}$ & $2 \cdot 24 \pm 0 \cdot 13^{\mathrm{b}}$ & $1 \cdot 22 \pm 0.07^{\mathrm{d}}$ \\
\hline
\end{tabular}

Values are mean \pm s.e.m. Group 1 follicles were obtained shortly before ovulation, Group 2 follicles shortly after ovulation.

Values with different superscript letters are significantly different, $P<0.05$ (Tukey's test).

Table 2. Concentrations of oestradiol and progesterone in the plasma and the ovarian follicle wall before and after ovulation in the hen

\begin{tabular}{|c|c|c|c|c|c|}
\hline \multirow{2}{*}{$\begin{array}{c}\text { Hours before }(-) \\
\text { or after }(+) \\
\text { ovulation }\end{array}$} & \multirow{2}{*}{$\begin{array}{l}\text { No. of } \\
\text { hens }\end{array}$} & \multicolumn{2}{|c|}{ Plasma (pg/ml) } & \multicolumn{2}{|c|}{ Follicle wall (pg/100 mg tissue) } \\
\hline & & Oestradiol & Progesterone & Oestradiol & Progesterone \\
\hline-9 & 6 & $194 \pm 14^{a}$ & $676 \pm 150^{a, d}$ & $1685 \pm 2 I^{a, b}$ & $3583 \pm 369^{a}$ \\
\hline-6 & 6 & $246 \pm 16^{a}$ & $1180 \pm 127^{\mathrm{c}}$ & $1705 \pm 222^{\mathrm{a}, \mathrm{b}}$ & $8573 \pm 582^{b}$ \\
\hline-3 & 6 & $315 \pm 18^{b}$ & $1753 \pm 83^{b}$ & $1723 \pm 253^{\mathrm{a}, \mathrm{b}}$ & $12162 \pm 552^{\mathfrak{c}}$ \\
\hline-1 & 4 & $320 \pm 16^{\mathrm{b}}$ & $1254 \pm 131^{\mathrm{c}}$ & $1623 \pm 295^{\mathrm{a}, \mathrm{b}}$ & $13420 \pm 910^{c}$ \\
\hline SGroup 1 & 7 & $308 \pm 17^{b, c}$ & $974 \pm 138^{\mathrm{a}, c, d}$ & $968 \pm 252^{\mathrm{a}}$ & $11418 \pm 720^{c}$ \\
\hline Q Group 2 & 7 & $261 \pm 23^{\mathrm{a}, \mathrm{c}}$ & $754 \pm 84^{d}$ & $1821 \pm 111^{6}$ & $4248 \pm 781^{\mathrm{a}, \mathrm{d}}$ \\
\hline+1 & 5 & $455 \pm 45^{\mathrm{d}}$ & $719 \pm 105^{d}$ & $2230 \pm 292^{\mathrm{b}}$ & $6606 \pm 758^{d}$ \\
\hline+2 & 5 & $408 \pm 31^{b, d}$ & $701 \pm 94^{d}$ & $2453 \pm 243^{b}$ & $5197 \pm 922^{d}$ \\
\hline+15 & 5 & $385 \pm 24^{b, d}$ & $720 \pm 80^{d}$ & $2612 \pm 387^{b}$ & $5523 \pm 798^{\mathrm{a}, \mathrm{d}}$ \\
\hline
\end{tabular}

Values are mean \pm s.e.m. Group 1 follicles were obtained shortly before ovulation, Group 2 follicles shortly after ovulation.

Values with different superscript letters are significantly different, $P<0.05$ (Tukey's test). 


\section{Discussion}

There are few reports of the changes in proteolytic enzyme activities of the ovarian follicle in relation to ovulation of mammalian and avian species (Espey \& Rondell, 1968; Parr, 1975; Espey \& Coons, 1976; Nakamura \& Nakajo, 1980). Nakamura \& Nakajo (1980) reported a significant decrease in the proteolytic enzyme of the ovarian follicle just before ovulation in the Japanese quail, but we found only a slight decrease in the neutral protease and no decrease in the collagenase or the acid protease before ovulation. This discrepancy may be due to the differences in the preparation of samples for the enzyme assay and the sort of enzymes determined; Nakamura \& Nakajo (1980) measured the alkaline protease in the supernatant of the homogenized follicle.

However, there was a significant rise in the neutral protease activity of the postovulatory follicle obtained a few minutes after the ovum had been extruded, but it decreased thereafter. Neutral protease is generally known as the enzyme that degrades the intracellular connective tissue (Oronsky, Ignarro \& Perper, 1974; Afting, Becker \& Elce, 1979). Yoshimura \& Fujii (1979) observed degradation of the interstitial structure in the granulosa layer of the hen follicle a few minutes before follicle rupture.

From our results, and those of others, we therefore suggest that the significant rise in the neutral protease of the postovulatory follicle is indicative of what occurs transiently at the time of ovulation. The neutral protease may therefore be an important factor in the degradation of the follicle structure at ovulation in the domestic fowl. Espey (1980) has suggested that, at ovulation in mammals, preovulatory surge of gonadotrophins may induce an inflammatory reaction which in turn would cause the actual rupture of the follicle. The neutral protease could be considered evidence for this hypothesis. On the other hand, Espey \& Coons (1976) concluded that collagenolytic enzymes could be active in the degradation of the follicle wall during ovulation in the rabbit. We found no significant change in the collagenolytic or acid protease activity of the preovulatory follicle; both increased with time after ovulation and seem to be more important in the resorption of the postovulatory follicle than in the ovulatory process, as observed in the case of the involution of the mammalian uterus after birth (Woessner, 1979).

As previously reported, progesterone levels in plasma and the follicle were high several hours before ovulation (Furr, Bonney, England \& Cunningham, 1973; Shahabi, Norton \& Nalbandov, 1975a; Shodono, Nakamura, Tanabe \& Wakabayashi, 1975). In the present study, as in that reported by Shahabi et al. (1975a), the plasma progesterone level had decreased just before ovulation, but the concentration in the follicle was still higher at that time. It is assumed that the retention of progesterone in the follicle may change as ovulation approaches. Exogenous $\mathrm{LH}$ significantly increases only progesterone values in the plasma and the follicle of the hen (Shahabi, Bahr \& Nalbandov, 1975b; Imai \& Nalbandov, 1978; Tojo \& Huston, 1980) and Rondell (1974) has reported a significant role for follicle progesterone in the ovulatory process of mammals. Oestradiol may also be involved in the ovulatory mechanism; after rupture, progesterone concentrations in the postovulatory follicle abruptly decreased, while those of oestradiol increased. Dick, Culbert, Wells, Gilbert \& Davison (1978) reported similar changes for these two steroids in the granulosa cells of the hen follicle during ovulation. We suggest, from the present results and those of others, that progesterone and the proteolytic enzymes, especially neutral protease, may be important in the ovulatory process after LH sensitization of the mature follicle in the domestic fowl, although the precise relationship that leads to rupture remains obscure.

We thank Mr M. Nishikawa and Mr K. Nishiyama for their helpful assistance. 


\section{References}

Afting, E. G., Becker, M.L. \& Elce, J.S. (1979) Proteinase and proteinase-inhibitor activities of rat uterine myometrium during pregnancy and involution. Biochem. J. 177, 99-106.

Dick, H.R., Culbert, J., Wells, J.W., Gilbert, A.B. \& Davison, M.F. (1978) Steroid hormones in the postovulatory follicle of the domestic fowl (Gallus domesticus). J. Reprod. Fert. 53, 103-107.

Espey, L.L. (1967a) Tenacity of the porcine Graafian follicle as it approaches ovulation. Am. J. Physiol. 212, 1397-1401.

Espey, L.L. (1967b) Ultrastructure of the apex of the rabbit Graafian follicle during the ovulation process. Endocrinology 81, 267-276.

Espey, L.L. (1970) Effect of various substances on tensile strength of sow ovarian follicles. Am. J. Physiol. 219, 230-233.

Espey, L.L. (1980) Ovulation as an inflammatory reaction-a hypothesis. Biol. Reprod. 22, 73-106.

Espey, L.L. \& Coons, P.J. (1976) Factors which influence ovulatory degradation of rabbit ovarian follicles. Biol. Reprod. 11, 483-503.

Espey, L.L. \& Lipner, H. (1965) Enzyme-induced rupture of rabbit Graafian follicle. Am. J. Physiol. 208, 208-213.

Espey, L.L. \& Rondell, P. (1968) Collagenolytic activity in the rabbit and sow Graafian follicle during ovulation. Am. J. Physiol. 214, 326-329.

Furr, B.J.A., Bonney, R.C., England, R.J. \& Cunningham, F.J. (1973) Luteinizing hormone and progesterone in peripheral blood during the ovulatory cycle of the hen (Gallus domesticus). J. Endocr. 57, $159-169$.

Imai, K. \& Nalbandov, A.V. (1978) Plasma and follicular steroid levels of laying hens after the administration of gonadotropins. Biol. Reprod. 19, 779-784.

Nakajo, S., Zakaria, A.H. \& Imai, K. (1973) Effect of the local administration of proteolytic enzymes on the rupture of the ovarian follicle in the domestic fowl, Gallus domesticus. J. Reprod. Fert. 34, 235240.

Nakamura, A. \& Nakajo, S. (1980) Proteolytic activity in the ovarian follicle wall of the Japanese quail
(Coturnix coturnix japonica) during normal and LH-induced ovulation. Jpn. J. Infert. 25, 198-202.

Oronsky, A., Ignarro, L. \& Perper, R. (1974) Release of cartilage mucopolysaccharide-degrading neutral protease from human leukocytes. J. exp. Med. 138, $461-472$.

Parr, E.L. (1974) Histological examination of the rat ovarian follicle wall prior to ovulation. Biol. Reprod. 11, 485-503.

Parr, E.L. (1975) Rupture of ovarian follicles at ovulation. J. Reprod. Fert., Suppl. 22, 1-22.

Pendergrass, P.B. \& Reber, M. (1980) Scanning electron microscopy of the Graafian follicle during ovulation in the golden hamster. J. Reprod. Fert. 59, 21-24.

Rondell, P. (1964) Follicular pressure and distensibility in ovulation. Am. J. Physiol. 207, 590-594.

Rondell, P. (1974) Role of steroid synthesis in the process of ovulation. Biol. Reprod. 10, 199-215.

Shahabi, N.A., Norton, H.W. \& Nalbandov, A.V. (1975a) Steroid levels in follicles and the plasma of hens during the ovulatory cycle. Endocrinology 96, 962-968.

Shahabi, N.A., Bahr, J.M. \& Nalbandov, A.V. (1975b) Effect of LH injection on plasma and follicular steroids in the chicken. Endocrinology 96, 969-972.

Shodono, M., Nakamura, T., Tanabe, Y. \& Wakabayashi, K. (1975) Simultaneous determinations of oestradiol-17 $\beta$, progesterone and luteinizing hormones in the plasma during the cycle of the hen. Acta endocr., Copenh. 78, 565-573.

Tojo, H. \& Huston, T.M. (1980) A significance of estradiol and progesterone in the ovulatory process of the domestic fowl. Jpn. J. Zootech. Sci. 51, $582-588$.

Tojo, H. \& Huston, T.M. (1981) Effects of steroid blockers on LH-induced ovulation in the domestic fowl, Gallus domesticus. J. Reprod. Fert. 61, 381386.

Woessner, J.FJ. (1979) Total, latent and active collagenase during the course of post-partum involution of the rat uterus. Biochem. J. 180, 95-102.

Yoshimura, Y. \& Fujil, S. (1979) Morphological changes of the stigma of follicle in the ovulatory process in the hen. Jpn. Poultry Sci. 16, 287-289.

Received 13 February 1981 